\title{
REAKSI PASAR TERHADAP PERISTIWA STOCK SPLIT DI BURSA EFEK INDONESIA
}

\author{
I PutuPurwata ${ }^{1}$ \\ I Gst. Bgs. Wiksuana ${ }^{2}$ \\ ${ }^{1,2}$ Fakultas Ekonomi dan Bisnis Universitas Udayana (Unud), Bali, Indonesia \\ email: Purwata_27@yahoo.com
}

\begin{abstract}
ABSTRAK
Penelitian ini bertujuan untuk mengetahui reaksi pasar terhadap peristiwa stock split yang diukur dengan mengamati perbedaan abnormal return (AR) dan trading volume activity (TVA) antara sebelum dan sesudah peristiwa stock split. Penelitian ini menggunakan pendekatan event study dengan periode pengamatan 10 hari sebelum peristiwa stock split, satu hari peristiwa stock split, dan 10 hari sesudah peristiwa stock split. Data sekunder diperoleh di BEI. Sampel pada penelitian ini sebanyak 43 perusahaan yang melakukan stock split pada tahun 2015 sampai 2017. Metode pengumpulan data yang digunakan dalam penelitian ini adalah data sekunder berupa harga saham, indeks harga saham gabungan dan volume perdagangan saham. Selanjutnya Uji hipotesis yang digunakan adalah Wilcoxon Signed Rank Test dengan menggunakan program SPSS versi 24. Kesimpulan dari penelitian ini adalah terdapat reaksi pasar yang terjadi, terlihat adanya perbedaan yang signifikan antara abnormal return (AR) dan trading volume activity (TVA) sebelum dan sesudah peristiwa stock split.
\end{abstract}

Kata kunci: reaksi pasar, peristiwa stock split, abnormal return, trading volume activity.

\begin{abstract}
This study aims to determine the market reaction to stock split events measured by observing the difference in abnormal return (AR) and trading volume activity (TVA) between before and after the stock split event. This study uses an event study approach with an observation period of 10 days before the stock split event, one day the stock split event, and 10 days after the stock split event. Secondary data is obtained on the IDX. The sample in this study were 43 companies that conducted a stock split in 2015 to 2017. The data collection methods used in this study were secondary data in the form of stock prices, joint stock price index and stock trading volume. Furthermore, the hypothesis test used is the Wilcoxon Signed Rank Test using the SPSS version 24 program. The conclusion of this study is that there is a market reaction that occurs, there is a significant difference between the abnormal return (AR) and trading volume activity (TVA) before and after the event stock split.

Keywords: market reaction, stock split, abnormal return, trading volume activity.
\end{abstract}




\section{PENDAHULUAN}

Pasar modal merupakan aktivitas yang berkaitan dengan kegiatan penawaran umum dan perdagangan efek. Pasar modal memiliki peranan yang sangat penting dalam perekonomian suatu negara. Pasar modal merupakan salah satu alternatif pendanaan perusahaan, hal ini berkenaan dengan pasar modal sebagai wadah untuk mempertemukan pihak yang memiliki kelebihan dana dengan pihak yang membutuhkan dana Pasarmodaljugadapatdiartikansemuapasaryangterorganisasimemperdagangkansah amsahamdanobligasidenganmemakaijasadariunderwriter.(SutejadanGunardi,2016:8). Pihak yang memiliki kelebihan dana dapat menginvestasikan dananya dengan harapan memperoleh keuntungan, sedangkan bagi pihak yang membutuhkan dana dapat memanfaatkan pasar modal untuk memperoleh dana tanpa harus menunggu dana operasi dari perusahaan.

Pasar modal (capital market) merupakan pasar untuk berbagai instrumen keuangan jangka panjang yang bisa diperjualbelikan, baik berupa surat utang (obligasi), saham,reksadana, instrumen derivatif lainnya (Aziz, $2015: 15$ ). Investasi di pasar modal dapat berbentuk utang jangka panjang dan penyertaan. Utang jangka panjang yaitu obligasi dan sekuritas kredit, seperti opsi, future, dan warrant, sedangkan penyertaan berbentuk saham. Berbagai jenis instrumen di pasar modal, saham merupakan instrumen yang paling menarik untuk diinvestasikan (Wiagustini, 2014:237). 
Berinvestasi di pasar modal khususnya saham, informasi merupakan alat yang sangat penting bagi Investor. Salah satu informasi yang ada di pasar modal adalah pengumuman tentang aktivitas perusahaan. Corporate action adalah kebijakan yang diambil perusahaan dengan tujuan untuk perbaikan kinerja dan menunjukkan performance dalam jangka pendek maupun jangka panjang.Corporate action sangat diperhatikan oleh Investor, keputusancorporate action disetujui dalam suatu rapat umum yaitu Rapat Umum Pemegang Saham (RUPS) atau Rapat Umum Pemegang Saham Luar Biasa (RUPSLB). Berbagai macam corporate action adalah right issue, stock split, pembagian bonus shares, stock deviden dan cash deviden.

Stock split merupakan salah satu corporate action yang dilakukan oleh perusahaan,Menurut (Fahmi, 2015:357) stock splitmerupakan perubahan nilai nominal perlembar saham dan menambah jumlah saham yang beredar sesuai dengan split factor. Apabila satu lembar saham dipecah menjadi tiga lembar saham, maka pemegang saham akan mendapatkan tiga lembar saham dari satu lembar saham terdahulu, dapat diartikan pula bahwa nilai nominal saham baru adalah sepertiga dari nilai nominal saham sebelumnya.

Keputusan suatu perusahaan melakukan stock splitdikarenakan melihat harga saham yang dinilai sudah terlalu tinggi sehingga berdampak kepada berkurangnya minat Investor dalam membeli saham perusahaan tersebut (Halim, 2015:118).Peristiwa stock splitakan membuat harga saham menjadi lebih rendah sehingga lebih mudah dijangkau oleh investor kecil, hal ini akan menimbulkan permintaan saham meningkat dan menjadi lebih likuid. Stock split memberikan 
sinyal positif karena manajer perusahaan akan menyampaikan tujuan di masa depan yang baik dari perusahaan ke publik yang belum mengetahuinya, ini berhubungan dengan seberapa cepat informasi diserap oleh pasar yang tercermin pada teori pasar efisien dalam penyesuaian menuju harga keseimbangan yang baru. Menurut (Jogiyanto 2015:547) Pasar Efisien merupakan reaksi pasar yang cepat dan akurat untuk mencapai keseimbangan baru yang sepenuhnya mercerminkan suatu informasi yang tersedia.

Peristiwa stock splitakan membuat harga saham menjadi lebih rendah sehingga lebih mudah dijangkau oleh Investor kecil, hal ini akan menimbulkan permintaan saham meningkat dan menjadi lebih likuid. Stock split memberikan sinyal positif karena manajer perusahaan akan menyampaikan tujuan di masa depan yang baik dari perusahaan ke publik yang belum mengetahuinya, ini berhubungan dengan seberapa cepat informasi diserap oleh pasar yang tercermin pada teori pasar efisien dalam penyesuaian menuju harga keseimbangan yang baru.

Ketersediaan informasi atas suatu peristiwa berkaitan dengan teori hipotesis pasar efisien (efficient market hypothesis) yang menyatakan bahwa harga saham yang terbentuk merupakan refleksi dari seluruh informasi yang ada (Jogiyanto, 2015:585). Teori efficient market hypothesis ini merupakan sebuah acuan utama bagi para Investor dalam mengambil keputusan di pasar modal, karena para Investor beranggapan bahwa informasi yang tersaji baik dari internal perusahaan maupun dari luar perusahaan adalah benar. 
Pengujian terhadap efisiensi pasar modal Indonesia berkaitan dengan corporate action yang dilakukan oleh perusahaan, dapat diukur dengan melihat abnormal return yang diperoleh oleh Investor. Abnormal return merupakan kelebihan dari return sesungguhnya terhadap return normal (Halim, 2015:95). Return normal adalah return yang diharapkan oleh Investor. Abnormal return ini digunakan sebagai alat ukur dalam kasus perusahaan yang melakukan stock split karena dapat mengetahui apakah Investor bereaksi terhadap informasi peristiwa stock split yang dilakukan oleh perusahaan.

Pengujian terhadap efisiensi pasar modal Indonesia selain menggunakan abnormal return dapat juga diukur melalui aktivitas perdagangan saham, dapat dilihat melalui indikator volume perdagangan. Pengaruh pemecahan saham (stock split) terhadap volume perdagangan saham dapat dilihat melalui aktivitas perdagangan saham, dapat diukur dengan trading volum e activity (TVA).

Trading volum e activity adalah alat ukur rasio antara total lembar saham yang diperdagangkan pada waktu tertentu terhadap total lembar saham yang beredar pada periode waktu tersebut.Trading volum e activitydigunakan sebagai indikator untuk melihat likuiditas suatu saham sebelum dan sesudah stock split. Terjadinya abnormal return dan trading volum e activitypada perusahaaan yang melakukan stock split mengindikasikan informasi yang dipublikasikan perusahaan direspon oleh Investor dan mengakibatkan adanya penyesuaian terhadap harga saham.

Penelitian yang mendasari stock splitterkait dengan reaksi pasar dilakukan oleh Gajeraet al. (2017) memperoleh hasil bahwa stock split berdampak positif 
terhadap harga saham serta meningkatkan likuiditas. Adnyani (2015)menemukan tidak ada reaksi pasar yang terjadi pada peristiwastock split.Penelitian yang dilakukan oleh Masry (2015) menunjukkan bahwa sebagian besar perusahaan yang melakukan pemecahan saham mencapai kenaikan harga setelah stock split.Joshipura (2014) dan Nadig (2015)menemukan tidak ada reaksi pasar yang terjadi, terlihat dari abnormal return, average abnormal returns danlikuiditas terhadap peristiwa stock split.

Penelitian yang dilakukan Chemmanur et al. (2015), Bodhanwala (2016) dan Adliah et al.(2017) menghasilkan terdapat perbedaan abnormal return yang diperoleh investor sebelum dan sesudah peristiwa stock split, namun tidak terdapat perbedaan trading volum e activity (TVA)sebelum dan sesudah peristiwa stock split. Jasmine (2015),Anggarini (2015)dan Fauzi et al.(2016) memperoleh hasil tidak terdapat perbedaan abnormal return yang diperoleh Investor sebelum dan sesudah peristiwa stock split, sedangkan dari volume perdagangan trading volum e activity (TVA) tidak terdapat perbedaan yang signifikan.

Hasil penelitian sebelumnya yang belum konsisten, terdapat indikasi adanya research gap dan ini membuka peluang untuk dilakukannya penelitian kembali. Penelitian ini dilakukan untuk menguji reaksi pasar terhadap peristiwa stock split yang difokuskan pada abnormal return dan trading volum e activity (TVA) sebelum dan sesudah peristiwa stock split pada perusahaan yang tercatat di Bursa Efek Indonesia. 
Berdasarkan latar belakang yang telah diuraikan, maka dilakukan pengujian kembali dengan rumusan masalah yaitu. Pertama, apakah terdapat perbedaan abnormal return saham sebelum dan sesudah peristiwa stock split?. Kedua, apakah terdapat perbedaan trading volume activity (TVA) sebelum dan sesudah peristiwa stock split?.

Tujuan penelitian ini adalah dapat memberikan kontribusi dalam bukti empiris mengenai abnormal return serta trading volume activity (TVA) sebelum dan sesudah stock split.Penelitian ini diharapkan dapat memberikan tambahan informasi bagi perusahaan mengenai dampak dari stock split sehingga dapat menjadi pertimbangan bagi perusahaan dalam mengambil suatu kebijakan corporate action serta dapat memberikan masukan atau pertimbangan bagi para investor untuk mengambil keputusan investasi pada emiten yang stock split.

Konsep pasar efisien menyiaratkan adanya suatu proses penyesuaian sekuritas menuju harga keseimbangan baru, sebagai respon atas informasi baru yang masuk ke pasar. Harga keseimbangan akan terbentuk setelah Investor sepenuhnya menilai dampak dari informasi yang tersedia. (Jogiyanto, 2015:519) mengklasifikasikan bentuk pasar yang efisien ke dalam tiga efficient market hypothesis (EMH).

Efisien bentuk lemah (weak form), semua informasi di masa lalu akan tercermin dalam harga yang terbentuk sekarang. Informasi di masa lalu tersebut tidak dapat digunakan untuk memprediksi perubahan harga pasar di masa yang akan datang, karena sudah tercermin pada harga saat ini.Efisien bentuk setengah kuat (semi strong), harga pasar yang terbentuk sekarang telah mencerminkan 
informasi masa lalu ditambah dengan semua informasi yang dipublikasikan. Return tidak normal hanya terjadi pada pengumuman suatu peristiwa sebagai representasi dari reaksi pasar terhadap pengumuman tersebut. Suatu pasar dikatakan setengah kuat apabila informasi terserap atau direspon dengan cepat oleh pasar.Efisiensi bentuk kuat (strong form), harga pasar yang terbentuk sekarang telah mencerminkan informasi masa lalu ditambah semua informasi yang dipublikasikan dan informasi yang tidak dipublikasikan. Pada pasar dalam bentuk kuat tidak akan ada seorang Investor yang mampu memperoleh return tidak normal.

Corporate action adalah tindakan strategis yang dilakukan oleh Emiten yang secara signifikan mempengaruhi jumlah dan harga Efek (saham atau obligasi) yang dikeluarkan oleh emiten (TICMI, 2016:8). Adapun jenis-jenis aksi korporasi yaitu:

1) Stock split

Stock splitadalah pemecahan nominal saham menjadi saham dengan nominal yang lebih kecil dengan rasio tertentu. 1 unit saham nilai nominal Rp. 1,000 dipecah menjadi 2 unit saham nominal Rp. 500.

2) Right Issue

Right Issue adalah pemberian hak kepada pemegang saham lama untuk memesan terlebih dahulu saham emiten yang akan dijual dengan harga nominal tertentu.

3) Dividen 
Dividen adalah pembagian laba kepada pemegang saham. Menurut UU PT no. 40 tahun 2007, dividen hanya dapat dibagikan emiten dengan saldo laba positif.

4) Shares Buyback

Shares Buyback/Stock Repurchase adalah pembelian kembali saham yang beredar di pasar oleh perusahaan penerbit/emiten. Kebijakan ini merupakan salah satu cara perusahaan untuk mendistribusikan kas yang dimiiki oleh perusahaan kepada pemegang saham selain dalam bentuk dividen.

5) Merger dan Akuisisi

Merger adalah penggabungan dua perusahaan atau lebih dan tinggal nama salah satu perusahaan yang bergabunng. Akuisisi adalah pembelian saham/aset perusahaan sasaran akuisisi yang mengakibatkan beralihnya pengendalian atas perseroan tersebut.

Stock split merupakan suatu kegiatan yang dilakukan oleh perusahaan dengan cara memecahkan nilai nominal saham menjadi lebih kecil. (Jogiyanto, 2015:321). Secara umum ada beberapa tujuan perusahaan melakukan stock split, yakni. Pertama, untuk meghindari harga saham yang telalu tinggi sehingga memberatkan Investor untuk membeli/memiliki saham tersebut. Kedua, mempertahankan tingkat likuiditas saham. Ketiga, menarik Investor yang berpotensi lebih banyak guna memiliki saham tersebut. Keempat, menambah jumlah saham yang beredar. Kelima, menerapkan diversifikasi investasi. 
Event Study dapat digunakan untuk mengkaji kandungan informasi terhadap setiap peristiwa. Jika suatu pengumuman tersebut mengandung infomasi, maka diharapkan pasar akan bereaksi pada waktu pengumuman diterima oleh pasar (Titin, 2013). Secara umum event study menyelidiki reaksi pasar terhadap kandungan informasi dari setiap pengumuman atau publikasi secara tertentu. Kandungan informasi dapat berupa berita baik (good news) atau berita buruk (bad news), peristiwa yang menjadi fokus penelitian dapat dikelompokkan kedalam beberapa jenis, antara lain yang paling sering dijumpai dalam studi peristiwa adalah: peristiwa konvensioanl, peristiwa kluster, peristiwa tak terduga, dan peristiwa yang terjadi bersifat relevan dan beruntun. Event study digunakan untuk mengukur efisiensi pasar dan dampak dari suatu peristiwa pada harga (Dutta, 2014).

Pembelian aset finansial keuntungan atau kerugian dari investasi ini disebut return. Total return atas investasi terdiri dari dua komponen, yakni capital gain (loss) dan yield. Capital gain (loss) merupakan selisih untung (rugi) dari harga investasi sekarang relatif dengan harga periode yang lalu. Yield merupakan presentasi penerimaan kas periodik terhadap harga investasi periode tertentu dari suatu investasi. Dalam ilmu keuangan return dibagi menjadi tiga jenis, yakni actual return,return ekspektasi, danabnormal return.

Reaksi pasar terhadap stock split dapat dilihat melalui perubahan penjualan dan harga. Perubahan harga akan mempengaruhi actual return saham melalui perubahan capital gain sehingga akan menimbulkan selisih antara return ekspektasi dengan return realisasi (abnormal return). Hasil penelitian yang 
dilakukan Hua (2013) memperoleh hasil abnormal return berpengaruh signifikan terhadap peristiwa stock split. Azhar et al.(2013) memperoleh hasil terdapat perbedaan yang signifikan abnormal return sebelum dan sesudah peristiwa stock split. Mittal (2015) dan Prasiska (2018) menemukan bahwa pasar bereaksi positif terhadap peristiwa stock split, dan terdapat perbedaan signifikan abnormal return. Hasil penelitian sebelumnya menunjukkan adanya perbedaan abnormal return yang signifikan sebelum dan sesudah peristiwa stock split, berdasarkan hasil tersebut maka dirumuskan hipotesis sebagai berikut:

$\mathrm{H}_{1}$ : Terdapat perbedaan abnormal returnyang signifikan sebelum dan sesudah peristiwa stock split.

Peristiwa stock split berpengaruh atau tidak terhadap suatu saham dapat dilihat melalui volume perdagangannya, baik sebelum mapupun sesudah peristiwa stock split. Trading volume activity (TVA)merupakan alat ukurnya, dapat terlihat apakah peristiwa stock split mempengaruhi reaksi pasar atau tidak. Hasil penelitian yang dilakukan Elistarani et al.(2014) memperoleh hasil bahwa ada perbedaan volume perdagangan dan likuiditas saham sebelum dan sesudah peristiwa stock split. Ginting(2014) dari hasil analisis didapatkan bahwa volume perdagangan saham sebelum dan sesudah stock split berbeda secara signifikan. Riyadi et al.(2013) memperoleh hasil terdapat perbedaan volume pada saat sebelum dan sesudah stock split.Patel et al.(2016) menemukan volume perdagangan menurun saat peristiwa stock split..Berdasarkan beberapa hasil penelitian sebelumnya, maka dapat dirumuskan hipotetsis sebagai berikut:

$\mathrm{H} 2$ : Terdapat perbedaan trading volume activity (TVA)yang signifikan sebelum dan sesudah peristiwa stock split.

\section{METODE PENELITIAN}


Penelitian ini merupakan penelitian yang termasuk dalam kategori event study atau studi peristiwa. Penelitian ini dilakukan pada perusahaan-perusahaan yang melakukan stock splitdan terdaftar di Bursa Efek Indonesia (BEI) periode 2015-2017, dapat diakses melalui alamat www.idx.co.id. Lokasi penelitian di Bursa Efek Indonesia (BEI) dipilih karena perusahaan yang terbuka sehingga memudahkkan dalam memperoleh data yang diperlukan, data-data yang dipublikasikan juga lebih akurat karena terseleksi dan diawasi oleh Otoritas Jasa Keuangan (OJK).

Ditinjau dari rumusan masalah dan hipotesis yang telah diuraikan, maka variabel yang akan dianalisis dalam penelitian ini adalah abnormal returndan trading volum e activity (TVA). Variabel ini akan diamati selama periode jendela 21 hari termasuk hari h pengumuman (10 hari sebelum, hari h dan 10 hari sesudah pemecahan saham).Variabel-variabel yang digunakan dalam penelitian adalah sebagai berikut ini.

\section{1) Abnormal Return}

Abnormal return merupakan selisih antara return yang sesungguhnyadengan return ekspektasi. Pengukuran abnormal return dapat dihitung dengan menggunakan langkah-langkah berikut ini.

a. Menghitung return saham individu yang sesungguhnya (return realisasi)

Return realisasi yaitu hasil keuntungan yang telah terjadi dan dihitung berdasarkan data historis. Returnsesungguhnya merupakan 
return yang terjadi pada waktu ke-t yang merupakan selisih harga sekarang relatif terhadap harga sebelumnya.

Return realisasi dapat dihitung dengan rumus seperti berikut ini.

$R_{i 1}=\frac{P_{t-P_{t-1}}}{P_{t-1}}$

Keterangan:

Rit $=$ Return saham pada hari ke-t

$\mathrm{P}_{t} \quad=$ Harga saham pada hari ke-t

$\mathrm{P}_{t-1} \quad=$ Harga saham pada hari ke $\mathrm{t}-1$

b. Menghitung return market

Return market dapat diperoleh dengan menggunakan persamaan berikut ini.

$K_{m}=\frac{l \quad[-l \quad[-1}{l i[-1}$

Keterangan:

$K_{m} \quad=$ Returnmarket pada hari ke-t

IHSG $_{t}=$ IHSG harian harian pada hari ke-t

IHSG $_{t-1}=$ IHSG harian pada hari ke $\mathrm{t}-1$

c. Menghitung return ekspektasi

Return ekspektasi yaitu return yang diharapkan akan diperoleh Investor di masa mendatang. Dalam penelitian ini, return ekspektasi dihitung menggunakan metode market model karena model ini mempunyai kemampuan mendeteksi abnormal return yang lebih baik dibandingkan dengan model yang lainnya. Market model memiliki potensi untuk menghasilkan tes statistik yang lebih sederhana, dengan menggunakan model ini akan dapat diperoleh 
model return ekspektasi yang mencerminkan karakteristik setiap sekuritas. Return ekspektasi dapat dihitung dengan rumus berikut ini.

$E\left(R_{L i}\right)=u_{l}+\beta_{l} \cdot R_{m}+E_{l i}$

Keterangan:

$E\left(K_{L i}\right)=$ Returnekspektasi sekuritas ke-i pada periode estimasi ke-t

$\alpha_{i}=$ Intercept untuk sekuritas ke-i

$\beta_{i}=$ Koefisien slope yang merupakan beta dari sekuritas ke-i

$\mathrm{R}_{\mathrm{mt}}=$ Return indeks pasar pada periode estimasi ke- $\mathrm{j}$ yang dapat dihitung dengan rumus: $\mathrm{Rm}_{\mathrm{t}}=\left(\mathrm{IHSG}_{\mathrm{t}}-\mathrm{IHSG}_{\mathrm{t}-1}\right) / \mathrm{IHSG}_{\mathrm{t}-1}$

$\varepsilon_{l i}=$ Kesalahan residu sekuritas ke-i pada periode estimasi ke- $t$

d. Menghitung abnormal return

Abnormal return dapat dihitung dengan menggunakan rumus berikut

ini.

$\mathrm{AR}_{i t}=\mathrm{R}_{i t}-E\left(K_{l i}\right)$

Keterangan:

$A R_{i t}=$ Abnormal return saham i pada perioda peristiwa ke-t

$R_{i t} \quad=$ Return Individual saham i sampai $\mathrm{t}$

$\mathrm{E}\left(\mathrm{R}_{i t}\right)=$ Returnekspektasi saham saat $\mathrm{t}$

e. Menghitung rata-rata abnormal return

$\mathrm{AAR}_{\mathrm{nt}}=\frac{\sum_{\mathrm{t}=1}^{n} \mathrm{ARit}}{\mathrm{n}}$

Keterangan:

$\mathrm{AAR}_{\mathrm{nt}} \quad=$ Rata-rata abnormal return saham pada hari $\mathrm{t}$

$\mathrm{n} \quad=$ Sampel

ARit = Abnormal return

f. Menghitung standar kesalahan estimasi 
$\mathrm{S}=\frac{\sqrt{\sum(R-K) 2}}{T 1-2}$

Keterangan:

$\mathrm{S}=$ Standar kesalahan estimasi

$\mathrm{R}=$ Rata-rata return saham i pada periode $\mathrm{t}$

$\mathrm{Ri}=$ Return saham ke I untuk hari ke $\mathrm{t}$ selama periode estimasi

$\mathrm{T} 1=$ Jumlah di periode estimasi

2) Volume Perdagangan Saham atau Trading Volume Activity (TVA)

Penelitian ini menggunakan volume perdagangan untuk mengukur besarnya likuiditas sebelum dan sesudah stock split. Data mengenai volume transaksi dan jumlah saham perusahaan yang beredar adalah volume transaksi harian selama 10 hari sebelum stock split dan 10 hari sesudah stock split.

a. Trading Volume Activity (TVA) dapat dihitung dengan rumus berikut ini.

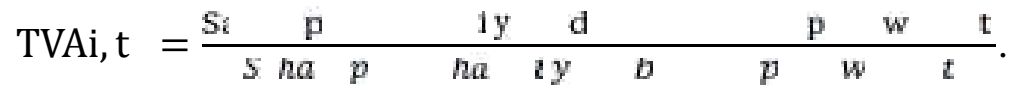

Keterangan:

TVA = Trading Volume Activity i pada waktu $\mathrm{t}$

$\mathrm{i}=$ Nama perusahaan

$\mathrm{t}=$ Waktu tertentu

b. Menghitung rata-rata volume perdagangan saham

$R-r \quad$ TVA $=\frac{\sum_{i \cdot 1}^{i k} T V A i}{n}$ 
Keterangan:

$$
\begin{array}{ll}
\mathrm{n} & =\text { Sampel } \\
\mathrm{TVAi} & =\text { Trading volume activity }
\end{array}
$$

Penelitian ini menggunakan event study untuk melakukan pengamatan pergerakan abnormal returndan trading volume activitydari hari ke hari dengan periode jendela peristiwa selama 21 hari. Penetapan peristiwa pemecahan saham adalah $\mathrm{t}=0$, periode jendela peristiwa dibagi menjadi dua golongan yaitu $\mathrm{t}=10(10$ hari sebelum pemecahan saham) dan $\mathrm{t}=10$ (10 hari sesudah pemecahan saham).

Populasi pada penelitian ini adalah perusahaan-perusahaaan yang terdaftar di Bursa Efek Indonesia (BEI), melakukan stock split pada periode 2015-2017. Teknik pengambilan sampel dilakukan secara purposive sampling yaitu sampel yang dibutuhkan dibatasi pada tipe tertentu atau menyesuaikan kriteria-kriteria yang ditetapkan oleh peneliti. Sampel-sampel dalam penelitian ini dipilih berdasarkan kriteria-kriteria sebagai berikut ini. Pertama, melakukan stock split selama tahun 2015 sampai dengan tahun 2017. Kedua, memiliki data yang dibutuhkan untuk penelitian secara lengkap. Ketiga, tidak melakukan corporate action lain selama periode pengamatan (event window), seperti right issue, warrant, additional shares, pengumuman dividen, saham bonus, merger.

Jumlah sampel perusahaan yang melakukan stock split periode 2015 -2017 adalah sebanyak 43 perusahaan.Metode pengumpulan data ini menggunakan data sekunder yang diperoleh melalui website resmi Bursa Efek Indonesia melalui www.idx.co.id, www.yahoofinance.com, www.sahamok.com dan indonesian capital market directory(ICMD) guna memperoleh informasi serta data yang diperlukan mengenai perusahaan yang melakukan stock split. 
Data kualitatif yaitu data yang berbentuk deskripsi, skema, dan gambar. Data kualitatif dalam penelitian ini adalah daftar nama perusahaan yang melakkukan stock split dan terdaftar di Bursa Efek Indonesia (BEI) periode 20152017.Data kuantitatif adalah data yang dapat dinyatakan dalam bentuk angka dan dapat diukur dengan satuan hitung.

Data kuantitatif yang digunakan dalam penelitian ini diantaranya tanggal peristiwa stock splityang digunakan sebagai event date (t0), harga saham penutupan harian perusahaan yang melakukan stock split dalam periode pengamatan, yaitu sepuluh hari sebelum peristiwa stock split, hari Hdan sepuluh hari sesudah peristiwa stock split, IHSGharian, jumlah saham yang diperdagangkan secara harian, danlisted share. Sumber data dalam penelitian ini diperoleh dari situs www.idx.co.id, www.yahoofinance.com, www.sahamok.com dan indonesian capital market directory(ICMD).

Setelah melakukan uji normalitas data, maka dilakukan pengujian statistik untuk menguji hipotesis. Jika data berdistribusi normal, maka uji statistik parametrik yang digunakan adalah paired sample t-test. Apabila data berdistribusi tidak normal maka digunakan uji statistik non parametrik yakni wilcoxon signed rank test. Tujuan pengujian ini adalah untuk mengetahui apakah pasar bereaksi terhadap peristiwa stock split, dengan menghitung abnormal return serta trading volume activity (TVA).

\section{HASIL DAN PEMBAHASAN}

Perusahaan yang melakukan stock split di Bursa Efek Indonesia pada periode 2015 -2017 terdiri dari berbagai jenis sektor perusahaan. Penelitian ini 
E-Jurnal Manajemen, Vol. 8, No. 4, 2019: 2352 - 2380

tidak memfokuskan pada satu sektor saja, adapaun sektor-sektor perusahaan yang melakukan stock split pada periode 2015 -2017.

Tabel 1.

Perusahaan Sampel Berdasarkan Sektor

\begin{tabular}{|c|c|c|c|c|c|}
\hline No & \multicolumn{3}{|c|}{ Sektor Industri Perusahaan } & Jumlah & Presentase \% \\
\hline 1 & \multicolumn{3}{|c|}{ Agriculture } & 1 & $2 \%$ \\
\hline 2 & \multicolumn{3}{|c|}{ Basic Industry and Chemicals } & 7 & $16 \%$ \\
\hline 3 & \multicolumn{3}{|c|}{ Consumer Goods Industry } & 9 & Std21\% \\
\hline 4 & Finance $\mathbf{N}$ & Minimum & Maximum & Mean8 & Dediation \\
\hline $\mathrm{t}-\overline{\mathrm{D}} 0$ & \multicolumn{3}{|c|}{ 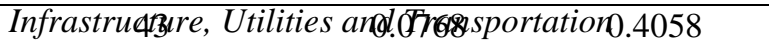 } & 0.19854 & 0.0659 \\
\hline$t-\varnothing$ & Mining 43 & 0.0895 & 0.4531 & 0.2074 & 0.06478 \\
\hline $\mathrm{t}-8$ & Miscellanßous Industry & 0.0632 & 0.4591 & 0.2146 & 0.07040 \\
\hline $\mathrm{t}-78$ & \multicolumn{3}{|c|}{ Property 4 Real Estate and 60 (1) } & 0.19834 & 0.07885 \\
\hline $\mathrm{t}-\theta$ & \multicolumn{3}{|c|}{ Trade, SeqBice and Invesno.0759 0.3606} & 0.1958 & $0.059 \%$ \\
\hline $\mathrm{t}-5$ & 43 & 010599 & 0.3658 & $0.200 \oplus 3$ & $0.01506 \%$ \\
\hline $\mathrm{t}-4$ & 43 & 0.0749 & 0.5833 & 0.2179 & 0.0875 \\
\hline$t-3$ & 43 & 0.0746 & 0.4520 & 0.2304 & 0.0885 \\
\hline
\end{tabular}

Tabel 2. 


\begin{tabular}{llllll}
$\mathrm{t}-2$ & 43 & 0.0170 & 0.4167 & 0.2011 & 0.0753 \\
$\mathrm{t}-1$ & 43 & -0.0062 & 0.6398 & 0.2271 & 0.1085 \\
$\mathrm{~T}$ & 43 & -0.9922 & -0.4165 & -0.7578 & 0.1798 \\
$\mathrm{t}+1$ & 43 & 0.0438 & 0.4623 & 0.2097 & 0.0825 \\
$\mathrm{t}+2$ & 43 & 0.0625 & 0.3422 & 0.2000 & 0.0700 \\
$\mathrm{t}+3$ & 43 & 0.0673 & 0.4526 & 0.2053 & 0.0732 \\
$\mathrm{t}+4$ & 43 & 0.0141 & 0.5328 & 0.2008 & 0.0917 \\
$\mathrm{t}+5$ & 43 & 0.01 & 0.50 & 0.1919 & 0.0745 \\
$\mathrm{t}+6$ & 43 & 0.0583 & 0.6183 & 0.2120 & 0.0887 \\
$\mathrm{t}+7$ & 43 & 0.0381 & 0.4287 & 0.1993 & 0.0794 \\
$\mathrm{t}+8$ & 43 & 0.0526 & 0.3515 & 0.1994 & 0.0659 \\
$\mathrm{t}+9$ & 43 & 0.0199 & 0.6793 & 0.2114 & 0.0986 \\
\hline $\mathrm{t}+10$ & 43 & 0.0188 & 0.3942 & 0.2015 & 0.0679 \\
Valid N & 43 & & & & \\
$($ listwise) & & & & & \\
\hline
\end{tabular}

Sumber: Data diolah,2018

Tabel 2. menjelaskan nilai maksimum, minimum, rata-rata dan standardeviasi. Pada H-10 nilai minimum sebesar 0.0768 didapat oleh perusahaanPrimarindo Asia Infrastucture Tbk dan nilai maksimum sebesar 0.4058diperoleholeh perusahaan Centex Tbk. Rata- rata abnormal return $\mathrm{H}-10$ bernilaipositif sebesar 0.1985 dan standar deviasi sebesar 0.0651 .

Rata-rataabnormal returnbernilaipositifdiperolehpadaH-10,H-9, H-8, H-7,
H-6,
H-5,
$\mathrm{H}-4$,
$\mathrm{H}-3, \mathrm{H}-2, \mathrm{H}-$

$1, \mathrm{H}+1, \mathrm{H}+2, \mathrm{H}+3, \mathrm{H}+4, \mathrm{H}+5, \mathrm{H}+6, \mathrm{H}+7, \mathrm{H}+8, \mathrm{H}+9 \mathrm{danH}+10$. Rata-

rataabnormalreturnnegatifdiperolehpadasaathariH.Rata-

rataabnormalreturntertinggidiperolehpadaH-3danrata-

rataabnormalreturnterendah diperoleh pada saat hari $\mathrm{H}$.

Tabel 3.

Hasil Uji Normalitas Abnormal Return Sebelum dan Sesudah Stock split One-Sample Kolmogorov-Smirnov Test

\begin{tabular}{llrr}
\hline & & $\begin{array}{c}\text { Abnormal } \\
\text { Return } \\
\text { Sebelum }\end{array}$ & $\begin{array}{c}\text { Abnormal } \\
\text { Return } \\
\text { Sesudah }\end{array}$ \\
\hline $\mathrm{N}$ & & 43 & 43 \\
Normal Parameters $^{\mathrm{a}, \mathrm{b}}$ & Mean & 0.209237 & 0.115795 \\
& Std. Deviation & 0.0603476 & 0.0379478 \\
\hline
\end{tabular}




\begin{tabular}{llrr}
\hline Most Extreme Differences & Absolute & 0.148 & 0.184 \\
& Positive & 0.148 & 0.184 \\
& Negative & -0.126 & -0.094 \\
Test Statistic & & 0.148 & 0.184 \\
Asymp. Sig. (2-tailed) & &, $019^{\mathrm{c}}$ &, $001^{\mathrm{c}}$ \\
\hline Sumber: Data diolah,2018 & & &
\end{tabular}

Berdasarkan Tabel 3 diketahui data berdistribusi tidak normal, hal tersebut dapat dilihat dari nilai Asymp. Sig(2-tailed)abnormal return sebelum dan sesudah peristiwa stock split lebih kecil dari level of signifikansi $\alpha=5 \%(0,019<0,05$ dan $0,001<0,05)$ sehingga alat uji hipotesis yang digunakan adalahuji nonparametrik Wilcoxon Signed Rank Test.

Berdasarkan Tabel 4. diketahui data berdistribusi tidak normal, hal tersebut dapat dilihat dari nilai Asymp. Sig(2-tailed)Trading volume activity sebelum dan sesudah peristiwa stock split lebih kecil dari level of signifikansi $\alpha=5 \%(0,00<$ $0,05$ dan $0,000<0,05)$ sehingga alat uji hipotesis yang digunakan adalah uji nonparametrik Wilcoxon Signed Rank Test.

\section{Tabel 4.}

Hasil Uji Normalitas Trading volume activity (TVA) Sebelum dan Sesudah Stock split One-Sample Kolmogorov-Smirnov Test

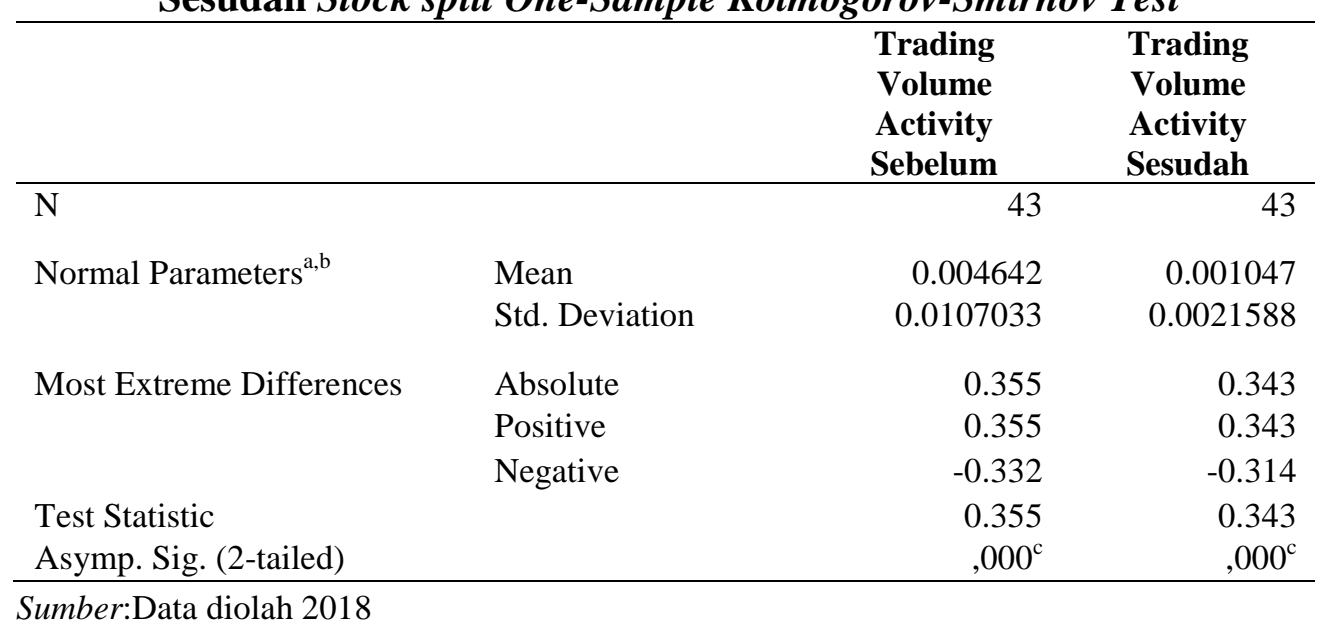


Pengujian Hipotesis dalam penelitian ini menggunakanWilcoxon Signed Rank Test. Berdasarkan hasil pengolahan yang diperlihatkan pada tabel 4 menunjukkan rata-rata hasil pengujian Sig(2-tailed $) 0.000<0.05$. Hasil pengujian menggunakan SPSS ini menunjukkan ada perbedaan yang signifikan abnormal return saham sebelum dan sesudah peristiwa stock split disepanjang periode pengamatan. Hasil pengujian juga menyimpulkan bahwa menolak Ho dan menerima $\mathrm{H} 1$.

Tabel 5.

Uji Wilcoxon Signed Rank Test Abnormal Return

\begin{tabular}{lr} 
& $\begin{array}{c}\text { Abnormal Return Sesudah - Abnormal } \\
\text { Return Sebelum }\end{array}$ \\
\hline $\mathrm{Z}$ & $-5,711^{\mathrm{b}}$ \\
Asymp. Sig. (2-tailed) & 0,000
\end{tabular}

Sumber: Data diolah,2018

Berdasarkan hasil uji hipotesis tersebut didapatkan signifikansi $0,000<0,05$ sehingga diperoleh bahwa $\mathrm{H} 1$ diterima atau rata-rata abnormal return sebelum dan sesudah peristiwa stock split terdapat perbedaan yang signifikan, maka Hoditolak.

Pengujian hipotesis dalam penelitian ini menggunakanWilcoxon Signed Rank Test. Berdasarkan hasil pengolahan yang diperlihatkan pada tabel 5 menunjukkan rata-rata hasil pengujian Sig(2-tailed $) 0.000<0.05$. Hasil pengujian menggunakan SPSS ini menunjukkan ada perbedaan yang signifikan trading volume activity saham sebelum dan sesudah peristiwa stock split disepanjang periode pengamatan. Hasil pengujian juga menyimpulkan bahwa menolak Ho dan menerima $\mathrm{H} 1$.

Tabel 6.

Uji Wilcoxon Signed Rank TestTrading volume activity (TVA) 
Trading Volume Activity Sesudah Trading Volume Activity Sebelum

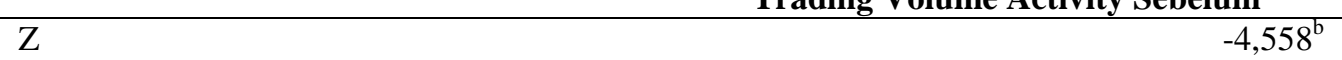

Asymp. Sig. (2-tailed) 0,000 Sumber: Data diolah,2018

Berdasarkan hasil uji hipotesis tersebut didapatkan signifikansi $0,000<0,05$ sehingga diperoleh bahwa $\mathrm{H}_{1}$ diterima atau rata-rata trading volume activitysebelum dan sesudah peristiwa stock split terdapat perbedaan yang signifikan, maka Ho ditolak.

Hipotesis 1 menyatakan bahwa terdapat perbedaan rata-rata abnormal return yang signifikan sebelum dan sesudah stock split. Berdasarkan analisis diperoleh nilai signifikansi $0.000<0.05$, hasil tersebut menunjukkan bahwa adanya perbedaan rata-rata abnormal return sebelum dan sesudah stock split. Hasil ini menunjukkan bahwa stock split memiliki kandungan informasi, sehingga Investor bereaksi dalam mengambil keputusan yang ditunjukkan dengan adanya perbedaaan abnormal return sebelum dan sesudah stock split. Abnormal return pada periode sebelum stock split dan sesudah stock split cenderung mengalami trend penurunan. Hasil penelitian ini mendukung teori efficient market hypothesis dimana pasar modal Indonesia termasuk dalam pasar efisien setengah kuat (semi strong). Teori ini menyatakan harga pasar saham yang terbentuk sekarang telah mencerminkan semua informasi yang dipublikasikan. Return tidak normal hanya terjadi pada pengumuman suatu peristiwa sebagai representasi dari respon pasar terhadap pengumuman tersebut.

Hasil penelitian ini mendukung penelitian yang dilakukan olehHernoyo (2013),B Suresha (2013), Azhar et al.(2013), Raisová et al.(2016), Saputra dan 
(2017)memperoleh hasil terdapat reaksi pasar yang terjadi, terlihat adanya perbedaan yang signifikan abnormal return sebelum dan sesudah peristiwa stock split. Rohit et al.(2016) memperoleh hasil yang sama bahwa adanya perbedaan abnormal return yang signifikan pada peristiwa peristiwa stock split. Adliah et al.(2017)menujukkan hasil terdapat perbedaan signifikan antara abnormal return sebelum dan sesudah peristiwa stock split.

Hipotesis $2\left(\mathrm{H}_{2}\right)$ menyatakan bahwa terdapat perbedaan trading volume activity yang signifikan sebelum dan sesudahstock split. Berdasarkan analisis diperoleh nilai signifikansi $0.000<0.05$. Perbedaan yang signifikan ini menandakan adanya reaksi pasar terhadap pengumuman stock split. Perbedaan trading volume activity pada penelitian ini dikarenakan adanya penurunan transaksi perdagangan yang dilakukan oleh pelaku pasar modal setelah peristiwa stock split. Ditandai dengan penurunan rata - rata trading volume activity sebelum pengumuman adalah 0.0046423 dan rata - rata trading volume activity sesudah pengumuman menjadi 0.0010473. Hipotesis ini mendukungteori efficient market hypothesisyaitu termasuk dalam pasar efisien setengah kuat (semi strong). Suatu pasar dikatakan setengah kuat apabila informasi terserap atau direspon dengan cepat oleh pasar, Investor bereaksi dengan cepat terhadap informasi mengenai stock split yang dilakukan oleh perusahaan, ini terlihat dari perbedaan trading volume activity yang signifikan sebelum dan sesudah stock split.

Hasil penelitian ini mendukung penelitian yang dilakukan oleh Elistarani et al.(2014)memperoleh hasil terdapat reaksi pasar yang terjadi, terlihat adanya perbedaan volume perdagangan dan likuiditas saham sebelum dan sesudah 
peristiwa stock split. Riyadi et al.(2013),Jaelani (2013), Nidia (2014), Korir (2016), Safira (2016) dan Utami (2017)memperoleh hasil sama yakni terdapat perbedaan volume pada saat sebelum dan sesudah stock split.Patel et al.(2016) menemukan volume perdagangan menurun saat peristiwa stock split.

Berdasarkan pembahasan dari hasil penelitian, maka implikasi dari hasil penelitian ini adalah abnormal return merupakan kelebihan dari return yang sesungguhnya terjadi terhadap return normal. Abnormal return berguna untuk melihat seberapa besar pengaruh suatu peristiwa (event) teerhadap harga suatu saham. Hasil penelitian ini menunjukkan bahwa terdapat reaksi pasar pada peristiwa stock split, terlihat adanya perbedaan abnormal return yang signifikan sebelum dan sesudah stock split. Stock split memiliki kandungan informasi, sehingga investor bereaksi dalam mengambil keputusan.

Abnormal return pada periode sebelum stock split dan sesudah stock split cenderung mengalami trend penurunan. Hasil penelitian ini mengindikasikan implikasi bahwa pasar modal Indonesia efisien setengah kuat, terlihat dari perbedaan abnormal return yang diperoleh investor dan ada penyesuaian harga pada saham perusahaan yang melakukan stock split.

Trading volume activity merupakan rasio antara jumlah lembar saham yang diperdagangkan pada waktu tertentu terhadap jumlah lembar saham yang beredar pada periode waktu tersebut.Trading volume activitydigunakan sebagai indikator untuk melihat likuiditas suatu saham sebelum dan sesudah stock split. Hasil penelitian ini menunjukkan bahwa terdapat perbedaan trading volume 
activityyang signifikan sebelum dan sesudah stock split. Perbedaan ini menandakan adanya reaksi pasar terhadap peristiwastock split.

Perbedaan trading volume activity pada penelitian ini dikarenakan adanya penurunan transaksi perdagangan yang dilakukan oleh pelaku pasar modal setelah peristiwa stock split. Hasil penelitian ini mengindikasikan implikasi bahwa pasar modal Indonesia efisien setengah kuat, terlihat dari perbedaan trading volume activity. Informasi terkait stock splityang dilakukan oleh perusahaan direspon cepat oleh iunvestor sehingga adanya penyesuaian terhadap volume perdagangan saham.

\section{SIMPULAN DAN SARAN}

Hasil pengujian abnormal return saham sebelum dan sesudah peristiwa stock split menunjukkan bahwa adanya perbedaan abnormal return sebelum dan sesudah stock split. Hasil ini menunjukkan bahwa stock split memiliki kandungan informasi, sehingga Investor bereaksi dalam mengambil keputusan yang ditunjukkan dengan adanya perbedaaan abnormal return sebelum dan sesudah stock split. Abnormal return pada periode sebelum stock split dan sesudah stock split cenderung mengalami trend penurunan.

Hasil pengujian trading volume activity saham sebelum dan sesudah peristiwa stock split menunjukkanbahwa terdapat perbedaan trading volum e activityyang signifikan sebelum dan sesudah stock split. Perbedaan ini menandakan adanya reaksi pasar terhadap peristiwa stock split. Perbedaan trading volume activity pada penelitian ini dikarenakan adanya penurunan transaksi perdagangan yang dilakukan oleh pelaku pasar modal setelah peristiwa stock split. 
Berdasarkan hasil penelitian dan simpulan diatas maka saran yang dapat diberikan adalah bagi investor, sebaiknya tidak berinvestasi pada perusahaan yang sedang melakukan corporate action berupa stock split karena peluang untuk memperoleh return terbilang kecil, dan sebaiknya dapat memanfaatkan corporate action lain untuk melakukan investasi.

Bagi emiten, sebaiknya tidak hanya melakukan corporate action berupa stock split untuk meningkatkan likuiditas perdagangan saham, karena sudah terbukti stock split tidak mampu meningkatkan likuiditas perdagangan saham serta abnormal return.Bagi penelitian selanjutnya, hendaknya bisa dikembangkan dengan meneliti reaksi pasar terhadap peristiwa stock split berdasarkan sektor. Penelitian per sektor ini diharapkan dapat menghasilkan temuan yang lebih akurat, karena sembilan sektor perusahaan yang ada di Bursa Efek Indonesia memiliki karakteristik yang berbeda.

\section{REFERENSI}

Adliah, Shabrina Nur, \& Nila Fiirdausi Nuzula. (2017). Analisis Abnormal Return Dan Trading Volume Activity Sebelumdan Sesudah Stock split(Studi Pada Perusahaan Go Public Periode 2014-2016). Jurnal Administrasi Bisnis (JAB),49(1), 162-168.

Adnyani, Ketut Sonya \&I.G.A.M. Asri Dwija Putri. (2015). Pengujian Kandungan Informasi pada Pengumuman Pemecahan Saham di Indonesia.E-Jurnal Akuntansi Universitas Udayana,10(1), 63-77.

Anggarini, Ni Putu Devi \& Ni Luh Putu Wiagustini. (2015). Dampak Pemecahan Saham Terhadap Likuiditas Dan Abnormal Return Di Bursa Efek Indonesia. E-Jurnal Manajemen Universitas Udayana, 4(3), 643-658. 
A Azhar, Al, Emrinaldi Nur DP \& M Alwi Montazeri. (2013). Analisis Abnormal Return Saham, Volume Perdagangan Saham, Likuiditas Saham, dan Variabilitas Tingkat Keuntungan Saham sebelum dan sesudah Stock split. Jurnal Akuntansi, 2(1), 37-46.

Aziz, Musdalifah, Sri Mintarti \&Maryam Nadir. (2015). ManajemenInvestasi: Fundamental, Teknikal,Perilaku Investor dan Retur Saham. Yogyakarta: Penerbit Deepublish.

B, Suresha \& Gajendra Naidu. (2013). An empirical study on price pressure and liquidity effect of stock split announcement" - Evidence from Indian market. International Journal of Marketing and Technology, 3(1), 138-156.

Bursa Efek Indonesia. (2018). http://www.idx.co.id/Diakses 10 September 2018.

Bodhanwala, Ruzbeh J. (2016). Stock split and reverse split- Evidence from India.Great Lakes Herald,10(2), 26-41.

Chemmanur, Thomas J., Gang Hu, \& Jiekun Huang. (2015). Institutional Investors and the Information Production Theory of Stock splits. Journal of Financial And Quantitative Analysis, 50(3), 413-445.

Dutta, Anupam. (2014). Parametric and Nonparametric Event Study Tests: A Review. International Business Research, 7(12), 136-142.

Elistarani, Putu Raras\& Ni Ketut Wijaya Kesuma. (2014). Analisis Perbandingan Abnormal Return dan Likuiditas Saham Sebelum dan Sesudah Stock Split. E-Jurnal Manajemen Universitas Udayana, 3(10), 3054-3066.

Fahmi, Irham. (2015). Manajemen Invstasi: Teoridan Soal Jawab, disi Kedua. Jakarta:Salemba mpat.

Fauzi,Shochihatuz Zainia, Suhadak,\&R. Rustam Hidayat. (2016). Pengaruh Peristiwa Stock SplitTerhadap Likuiditas Saham dan Return Saham (Studi pada Perusahaan yang Terdaftar di Bursa Efek Indonesia Periode 20122014). Jurnal Administrasi Bisnis, 38(2),156-162.

Gajera, Alpesh,Priya Mansata\&Shreya Virani. (2017). Risk and Return Analysis Of Selected StockBefore and After Split. International Journal for Innovative Research In Multidisciplinary Field, 3(5),106-109.

Ginting,Selaras Christiani\& Henny Rahyuda. (2014). Perbedaan Volume Perdagangan Saham Dan Abnormal Return Sebelum dan Sesudah Peristiwa Stock split Pada Perusahaan Di Bursa Efek Indonesia. E-Jurnal Manajemen Universitas Udayana, 3(6), 1571-1589. 
Halim, Abdul. (2015). Analisis Investasi danAplikasinya. Jakarta: Salemba mpat.

Hernoyo, Muhammad Ade. (2013). Pengaruh Stock split Announcement Terhadap Volume Perdagangan dan Return. Management Analysis Journal, 2(1), 110116.

Hua, Liu \& Skanthavrathar Ramesh. (2013). A Study on Stock split Announcements and itsImpact onStock Prices in Colombo StockExchange (CSE) of Sri Lanka.Global Journal of Management and Business Research Finance, 13(6), 25-34.

Jaelani. (2013). Stock split Policy on Signal and Liquidity Motivewith Implications to Retail Investor. International Journal of Science and Research (IJSR), 2 (6), 426-431.

Jasmine, Aldila Vania\& Leo Herlambang. (2015). Reaksi Pasar Atas Stock split Pada Emiten Saham Syariah Di Bursa Efek Indonesia Periode 2011-2014. Jurnal Ekonomi Syariah Teori dan Terapan,2(8), 658-672.

Jogiyanto, H. M. (2015). Teori Portofolio dan Analisis Investasi. Yogyakarta: BPFE-Yogyakarta.

Joshipura, Nehal. (2014). Market Reaction to Stock splits in Large and Liquid Stocks. NMIMS Management Review, 24(3), hal. 130-140.

Korir, Sammy Kipruto, Albert Onyango Odhiambo \&Peter Wawirec. (2016). Stock splits and Performance of Firms Listed at the Nairobi Securities Exchange, Kenya.International Journal of Sciences, 29(2), 168-178.

Masry, Mohamed. (2015). The Impact of Stock split on Stock Prices in the Egyptian StockMarket.Research Journal of Finance and Accounting, 6(20), 116-135.

Mittal, Dr. Swati. 2015. Stock Market Reactions to Announcements of Stock Splits. Journal of Management Sciences and Technology, 2(2), 52-58.

Nadig, Asha. (2015). An Empirical Study of Stock split Announcements of Select BSE Sectors using Event Study Methodology.Journal of Management, 6 (1), 1-12.

Nidia, Ratih Rr. (2014). Analisis Volume Perdagangan Saham dan Abnormal Return Sebelum dan Sesudah Pemecahan Saham Pada Perusahaan yang Terdaftar Di Bursa Efek Indonesia. Jurnal Akuntansi Unesa, 3(1), 1-26. 
Patel, Mitesh, Dr. Munjal Dave \&Dr. Mayur Shah. (2016). Stock Price And Liquidity Effect Of Stock split: Evidence From Indian Stock Market. International Journal Of Management Research \& Review, 6(8), 10301039.

Prasiska,Yuliana, \& Nila Firdausi Nuzula. (2018). Analisis Abnormal Return dan Bid-Ask Spread Sebelum dan Sesudah Stock split (Studi Pada Perusahaan Go Public di BEI Tahun 2013-2017). Jurnal Administrasi Bisnis, 59(1), 6167.

Raisová,Martin Užik \& Christian M. Hoffmeister. (2016). Normal and reverse stock splits in the V4 countries. Investment Management and Financial Innovations, 13(4), hal. 94-105.

Riyadi, Selamet,\& Selvi Andrefa. (2013). Analisis Dampak Stock split Terhadap Harga, Volume dan Keputusan Investasi Pada Saham. e-Jurnal Manajemen dan Bisnis, 1(1), 1-24.

Rohit, babitha Prakash Pinto, \&Shakila B. (2016). Impact of Stock splits and RightsIssue Announcements on Market Price: Evidence From India.A Management Journal,7(2), 1-16.

Safira, Tania Hayu\& Febryanti Simon.(2016). Uji Komparasi Abnormal Return, Trading Volume, Trading Frequency, dan Bid-Ask Spread Sebelum dan Sesudah Share Split. Jurnal ULTIMA Accounting, 8(2), 24-45.

Saputra, Indra. (2017). Perbedaan Harga Saham Sebelum dan Sesudah Peristiwa stock split pada Perusahaan yang Listing Di Bursa Efek Indonesia Periode 2008-2013. Jurnal Ekonomi dan Bisnis, 10 (1), 14-26.

Suteja, Jaja \&Ardi Gunardi. (2016). Manajemen Investasi dan Portofolio. Bandung: PT Refika Aditama.

TICMI. (2016). Pengetahuan tentang Efek Index Efek dan Aksi Korporasi. Jakarta.

Titin. (2013). Perbandingan Return dan Abnormal Return, sebelum dan sesudah Hari Raya Idul Fitri (Study Reaksi Pasar). Jurnaal Ekbis, 6(1), 350-357.

Utami, Anita Tri. (2017). Analisis Trading Volume Activity dan Average Abnormal Return Sebelum dan Sesudah Melakukan Pemecahan Saham (Stock split) Pada Perusahaan yang Terdaftar Di Bursa Efek Indonesia. Jurnal Ekonomi Bisnis, 18(2), 164-173.

Wiagustini, Ni Luh Putu. (2014). Dasar-dasar Manajemen Keuangan. Denpasar: Udayana University Press. 
E-Jurnal Manajemen, Vol. 8, No. 4, 2019: 2352 - 2380

Yahoo finance. (2018). https://finance.yahoo.com/ Diakses 10 September 2018. 